\title{
Ethical perceptions of employees in small retailing firms: A case of indigenous-owned fast-food outlets in Zimbabwe
}

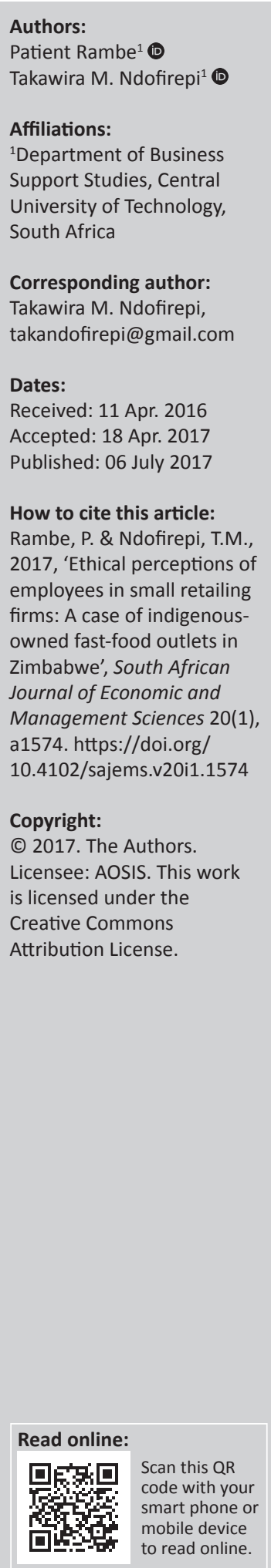

Background: Although the subject of ethical business practices has a well-established tradition in large corporations where shareholder value maximisation is largely dependent on such entities' conduct of good business ethics, its investigation in small businesses in agile, economically depressed economies such as that of Zimbabwe has targeted business owners and managers but excluded their employees. Given the middleman role that employees of emerging indigenous-owned retail firms play in the distribution chain from manufacturers to the consumers, the ethical perceptions of these employees are critical to the leveraging of businesses' strategic orientations. Employees are the coal face of the firm, withering intense competition from these firms' rivals and achieving the firms' strategic orientations (profitability, market share, business growth and survival). In order to meet stakeholder expectations simultaneously largely depends on the ethical conduct of such employees.

Aim: The overall aim of this study is to contribute to ethical theory and literature by demonstrating how employees' ethical perceptions and behaviour shape the strategic orientations of the business. To achieve this aim, the study sought to: (1) establish the typical ethical dilemmas that employees of these retail firms faced in their daily tasks, (2) assess how they responded to these ethical challenges, (3) ascertain whether demographic factors such as age, level of education, gender and their position in the organisational hierarchy influence their reaction to ethical dilemmas; and (4) determine these employees' overall perceptions of ethical issues within their organisations.

Setting: The study was conducted on employees of an indigenous-owned fast-food firm operating in two cities in Zimbabwe.

Methods: A survey was conducted on 108 employees working in two cities. A structured questionnaire was developed and administered to the employees.

Results: The results suggested that a majority of the respondents were ethically conscious and could make ethical choices. In addition, most respondents deemed the ethical scenarios presented to them as morally wrong, suggesting that the surveyed employees wished to engage in ethical behaviour. However, while the respondents were deemed to be ethically astute in their individual capacities, they seemed to lack an in-depth knowledge of the ethical policies of their organisation.

Conclusion: The study concludes that owners and managers of small firms should provide interventions to cascade ethical policy to the lower ranks of the organisation to enhance the ethical perception amongst employees of these firms. The study implication is that an institutional top-down approach is critical to embedding ethical sensitivity into employees without which employees may continue to speculate about the business ethics of their organisation.

\section{Introduction}

The business ethics of large corporations have attracted considerable attention in both developed and developing world contexts. The reasons for such interest are: these entities' dependence on relationships of trust with their customers (Institute of Business Ethics 2007; Martínez \& Del Bosque 2013), print and electronic media's obsession with ethical failures and scandals of large, publicly-traded corporations (Fassin 2005; Fassin, Van Rossem \& Buelens 2010; Huimin \& Ryan 2011; Longenecker et al. 2006) and the concern of leaders in business and government on the moral climate of the corporate world (Longenecker Moore et al. 2006). 
Although the ethical practices of large business entities have been explored extensively, the business ethics of small, micro and medium enterprises (SMMEs) in developing economies have received minimum attention (Murillo \& Lozano 2006; Painter-Marland \& Spence 2009; Okyere 2012; Spence \& Rutherfoord 2003). Yet, the issue of ethical behaviour and indiscretion in business is a concern for all companies, regardless of size (Longenecker et al. 2006). In fact, literature acknowledges the dire need for more concerted research in various areas of small business ethics studies (Dees \& Starr 1992; Painter-Marland \& Spence 2009; Phatshwane 2013). The exploration of the ethical conduct of SMMEs in developing economies is critical to understanding the strategic choices of the SMME managers and owners (and employees) that optimise the profitability of their businesses (Fassin et al. 2010; Garray \& Font 2012; Spence \& Lozano 2000). Business ethics are also key to SMMEs' survival in volatile and highly competitive environments characteristic of developing countries. Spence and Lozano (2000) argue that the relevance of the small firms' ethics to economic and social environments, especially those of emerging economies, is too significant to be disregarded, and discussions about ethics are pivotal to addressing particular ethical strains on SMMEs.

The nascent literature on small business ethics tends to be preoccupied with managers and owners of these firms (Institute of Business Ethics 2007; Longenecker et al. 2006) and ignores employees' perceptions of organisational ethics. Perhaps the interest in SMME managers and owners at the expense of employees lies in the fact that managers and/or owners normally bear the brunt of breach of trust in the event of ethical malpractices. An example of such breach of trust is when suppliers deliberately fail to meet the agreed terms and conditions of supplying products or services (Institute of Business Ethics 2007). More so, because the small business is generally the prime source of income for small business managers and owners and consumes a majority of their resources and time (Fassin et al. 2010), researchers are naturally inclined to investigate the managers' and owners' ethical conduct as it directly affects the successful performance and survival of the business. However, because employees tend to deal more directly with customers compared with their managers, it might mean that the intimate nature of the small business-customer relationship makes it highly susceptible to the debilitating and potentially disastrous consequences of unethical behaviour (Humphreys et al. 1993). Therefore, mitigating the negative consequences of unethical behaviours of employees is foundational to promoting the growth of small businesses. The few researchers that studied employee perceptions of ethics targeted employees of large public and private organisations (Basran 2012), or explored their gender-based perceptions of organisational ethics in the developed world (McDaniel, Schoeps \& Lincourt 2001).

In view of the paucity of research on employee perceptions of ethical conduct of the small organisations that employ them, especially SMMEs, this study explored how employees would perceive and respond to typical ethical dilemmas they could be confronted with on a daily basis. The study also explored employees' perceptions of the business ethics of their organisation. More specifically, the study sought to: (1) establish the typical ethical dilemmas that employees faced in their daily tasks, (2) assess how they responded to these ethical challenges, (3) ascertain whether demographic factors such as age, level of education, gender and one's position in the organisational hierarchy influenced his or her reaction to ethical dilemmas and (4) determine the extent of employees' perceptions of ethical issues within their organisations.

The rest of the article is arranged as follows: Firstly, the study background is provided and relevant literature on the area of study is reviewed. This is then followed by the research methodology used in the study. The findings are then analysed and discussed. This article then concludes with the practical and theoretical implications of the research and suggestions for future research.

\section{Problem background}

Zimbabwe grappled with a hyperinflationary environment between the years 2000 and 2008. This culminated in unprecedented inflation levels of 231 million per cent by July 2008 when it was last calculated officially by the Central Statistical Office (Biti 2015). The IMF team that visited Zimbabwe in March 2009, however, calculated that inflation peaked at 500 billion per cent in September 2008 (Biti 2015). Kabote, Chimutingiza and Mirimi (2013) provide an illuminating account of the dollarisation process. To cushion themselves from the hyperinflationary environment, Zimbabweans resorted to the use of the US dollar and South African rand, hence unofficially dollarising the economy which was considered illegal then (pre-official dollarisation stage). In November 2008, Reserve Bank of Zimbabwe issued licences to tourism businesses to trade in foreign currency (Reserve Bank of Zimbabwe2008), with the rest of the economy continuing to use the Zimbabwean dollar (the semi-official dollarisation phrase). Zimbabwe was officially dollarised in February 2009, presenting its national budget in US dollar although other major currencies were allowed to be used for trading purposes (official dollarisation stage) (Kabote et al. 2013).

In the post-dollarisation stage, the Zimbabwean fast-food sector experienced significant growth, with a number of new players entering the market (Mkono 2012). Research and markets (2011) reported on McDonalds, the global fast-foods giant's plans to penetrate the Zimbabwean market in September 2010. This strategic move was made against a backdrop of economic conditions and the attractiveness of the Zimbabwean market. Initially, the multinational firm had attempted to penetrate the market in 1999 but later floundered because of perceptions of economic and political risks in the country at the time (Research and Markets 2011). In September 2010, the post-dollarisation phase, Innscor, a leading player in the fast-food industry, projected an annual sales growth of $25 \%$ per annum by July 2011. The firm also reported sales 
revenue of USD 512996433 in December 2015 from its local operations (Innscor Report 2014). The generation of sales revenue by local companies and the entrance of other international firms contributed to a positive outlook of the Zimbabwean fast-food sector.

The positive outlook of the local fast-food market has attracted more players into the industry, with a number of international franchises also entering the fray. For example, Kentucky Fried Chicken (KFC) returned to Zimbabwe in early 2014, intensifying competition and generating discomfort amongst old players (Mkono 2012). Established businesses have also employed aggressive tactics against competitors to remain economically viable and reduce competition. For example, when Innscor reduced prices drastically, many fast-food SMMEs became more vulnerable and were compelled to close their businesses because of loss of competitiveness and declining profits. The pressure to survive and to reduce business rivalry has intensified the temptation to engage in unethical practices (Brizek 2014). In view of such competition from rivals, small Zimbabwean fast-food firms have been compelled to impose tough performance targets on their employees. This pressure coupled with the 'free-for-all' economic phase the country has just emerged from served as an ideal breeding ground for employee unethical behaviour. It seems the widely condemned business scandals like the McDonalds horse meat and Chinese expired tinned meat scandals have done little to deter similar ethical transgressions in the fast-food industry in emerging economies. Although larger firms often have a semblance of ethical programmes in place to guide their employees' conduct, good ethical behaviour is not so obvious for most SMMEs, as rules of engagement are often informal and undocumented. The grey areas in Zimbabwean SMME employees' ethical behaviour have increased the calls for ethical sensitivity and morally responsible business practices (Masaka 2011; Mawere 2011). Yet, to our knowledge, no concerted efforts have been made to investigate the SMMEs' ethical conduct, especially the ethical perceptions of their employees in the small fast-food industries in the country.

\section{Literature review \\ A case for employee perspectives on organisational ethics: An overview}

The under-exploration of SMME employee ethics is unfortunate as ethically sensitive employees are considered to make independent decisions that are consistent with the company's culture, objectives and values, thus improving organisational efficiency, reducing the levels of supervision required and increasing their adaptation to changing roles and responsibilities (Ethic Resources Centre 2010). More so, an employee's positive perceptions of an organisation's ethical culture are associated with higher levels of engagement in the organisation (Ethic Resources Centre 2010).

Limited consideration of employee's ethical practices can be attributed to the authoritarian-paternalistic style of management of small businesses in which the main business functions (such as marketing, product development sales, finance etc.) of the organisation are monopolised by the manager or owner whose approaches to these issues are based on their personal experiences, standards and judgement (Spence \& Lozano 2000; Vivier 2013). Most SMMEs are owner-managed and the owners are directly involved in the day-to-day activities of the company, often undertaking multiple roles and functions (Vivier 2013). The centrality of the small business managers and owners in decision making processes, therefore, has made them the ideal candidates for investigation, thereby unintentionally excluding employees who actually have more direct contact with clients and other stakeholders. The paternalistic orientation of SMME managers and owners lies in the sense that they, in the execution of their tasks, rely on employees with limited scope for critical decision making, but who are more often rewarded for their support for the manager's decisions (Spence \& Lonzano 2000).

Despite the immense potential of employees in advancing the economic and ethical interests of the organisation (Institute of Business Ethics 2007; Vivier 2013), their perspectives on organisational ethics have received marginal attention in business management literature (Dhanesh 2012; Paillé et al. 2014; Ruiz-Palemino, Martínez-Cañas \& Fontrodona 2013; Slack, Corlett \& Morris 2014). Although concepts related to business ethics are alluded to in these two aforementioned studies, the studies focused more on corporate social responsibility (CSR) and not business ethics in particular. As such, it is vital to underscore that although some complementarities and an increasing overlap have been observed between business ethics, CSR and corporate governance (Cornelius, Van den Berghe \& Louche 2005; Fassin et al. 2010), these concepts have also evolved independently over time. This scenario clouds and complicates any attempt to categorise various researches into the issues of ethics and CSR. Although CSR relates to '...the complex and multifaceted relationships between business and society, and tries to account for the economic, social and environmental impacts of business activity' (Jamali, Dirani \& Harwood 2015:1), the subject of business ethics is confined to the morality of business activities and can be viewed at both the organisational and individual levels.

This under-exploration of SMME employees ignores the fact that they are often the primary stakeholders for SMME managers and owners (Klein \& Vorbohle 2010; Vivier 2013) and where contractual arrangements (e.g. through employee ownership programmes) exist between the manager or owner and the employees, the latter often enjoy a mutual commitment to shared values as well as to the welfare of the group (Barnett \& Schubert 2002; Sledge \& Miles 2012).

\section{An overview of business ethics}

Although the definition of ethics is heavily contested, there is some consensus that the term entails moral values and dilemmas in everyday contexts. Shaw (2014) defines ethics as 
principles or values that guide behaviour. Within the organisational settings, these values are embodied in virtues such as honesty, compassion and loyalty (Velasquez 2006). Because ethics deal with distinctions between right and wrong (Ferrell, Fraedrich \& Ferrel 2014), they are founded on morality, which includes moral judgement, standards and rules of conduct (Parboteeah \& Cullen 2013). Moral judgements may relate to decisions on fair, honest and competent pricing of products, while standards emphasise providing the appropriate service and product offerings of the expected quality and required quantity at the appropriate places and times.

Cant, Wiid and Kallier (2013) define business ethics as:

the commonly agreed upon principles, rules, behaviour and conduct that should be followed in the business environment. It is the moral code of conduct of the business, what is right or wrong, good or bad. (p. 5776)

Business ethics, therefore, are a set of moral principles for arriving at a decision, which is consistent with the values of an organisation (Holme 2008). Ethical business values shape and inform management behaviour and can directly influence employee satisfaction and their job performance (Holme 2008). The direct relationship amongst corporate ethical values, employee satisfaction and firm performance stems from the building of trust (Hosmer 1994). It can be inferred that where SMME employee-stakeholder relations of trust prevail, business performance and survival are more guaranteed than where relations of mistrust are bred. Yet, the application of ethical values varies across contexts. For example, sustaining honest relationships with customers is critical for marketers (Abratt, Bendixen \& Drop 1999) and sensitivity to various market-related factors is a fundamental moral consideration for marketers (Rao et al. 2001), while the need to trust business is non-negotiable for consumers (Singhapakdi, Vitell \& Franke 1999). More so, the impact of organisational ethics on employee behaviour is unclear. Sharma, Borna and Stearns (2009) surveyed 400 chain furniture retail outlets in southern USA to explore such a relationship. Their findings suggest that although there is a direct relationship amongst corporate ethical values and employee and customer behaviour, other variables seemed to mediate that relationship.

\section{Normative ethics and small, micro and medium enterprise conduct}

Because this study examines SMME employees' perceptions of organisational ethics, the normative ethics, standards and rules are worthy of examination. Normative ethics deal with what actions one ought to or ought not to perform (Morris et al. 2002). They also are concerned with whether those actions are good or bad, right or wrong, virtuous or vicious, worthy of praise or blame or worthy of a reward or punishment (Smith \& Hasnas 1999). In an SMME context, normative ethics relate to the moral standards and rules that govern SMME employees' conduct with the internal (i.e. with their managers or owners, and peers) and external world (customers, suppliers, investors and government agencies). These range from safety of employees and stakeholders in the business context, honesty and trustworthiness in the distribution chain (from sourcing of raw materials to final disposal of product), socially acceptable marketing practices and fair pricing to refraining from misrepresentation of the contents of products or constitution of services.

Normative ethics have two main sub-areas, namely virtue ethics and rule-based ethics. Virtue ethics are about entrenching goodness in everything that one does (Van Hooft \& Van Hooft 2014). Therefore, ethical conduct such as patience, courtesy and humility towards customers and suppliers could be fundamental to effective SMME relationships with their stakeholders, particularly in view of the intimate and personal relations between them. Although the aforementioned ethical conduct can be expressed as good customer relations, desisting from ethical constraints such as bribery, theft, coercion, deception and unfair discrimination, which constrains the freedom of the business to make decisions, (Botha 2012:5) is all expressions of business ethics.

Virtue ethics can also relate to intra-organisational relations such as employee-peer relations and immediate superioremployee relations such as fair compensation for employees, decent and human working conditions and fair and equal treatment amongst other considerations. Virtue ethics seem to be more inclined to maintaining good employer-employee relations than entrenching business ethics, which should focus on customers and other stakeholders. Virtue ethics need to be distinguished from ethical misconduct such as bribery, which alters the conditions under which a decision is made and results in the business allocating more recourse to options that are less favourable for the business (Botha 2012; Cant et al. 2013). The same is applied to coercion of customers, which results in the altering of the value and belief system of the organisation, which can result in an unhealthy work environment (Davoren 2013) and loss of loyal customers.

Because SMME managers or owners tend to consider employees as the bedrock of a company, the SMME normally regards employees' health and well-being as their sole responsibility (Seeletse \& Ladzani 2012; Vivier 2013). Although employee welfare is a component of the broader regime of ethics, the importance of ethics to SMMEs compared with larger businesses needs to be acknowledged. Cant et al. (2013) reiterate that small businesses are more prone to ethical issues because of their size, while large businesses are more equipped to deal with ethical issues and decisions. They elaborate that large businesses tend to have a corporate environment and set rules and regulations that help prevent ethical problems. This can be contracted with SMEs, which do not have the same resources and expertise to handle ethical problems that arise (Assad 2013; Cant et al. 2013).

Rule-based ethics are a form of normative ethics that is prescriptive in nature. They attempt to provide a guideline to ethical behaviour (Carroll \& Buccholtz 2014). Rule-based 
ethics are conceived as either consequentialist or deontological. Consequentialism seeks to evaluate actions on the basis of their results, in particular their utilitarian consequences. Based on this principle, an action is deemed to be ethical if it brings more happiness to a group than an individual (Boyle 2002). People in communities guided by such consequentialism, therefore, are often prepared to surrender individual happiness for the sake of community contentment. SMME employees may, therefore, prioritise availing goods to the community at the expense of profiteering. However, the challenge is that employees' ethical decisions regarding consequentialism may remain unknown as the manager or owner tends to make such decisions at their expense.

Deontology examines the goodness or correctness of an action on the basis of the intrinsic goodness of the action, rather than their end result. Hence, deontology simply outlines moral duties without paying attention to the subsequent compensation or penalty (Boylan 2002).

\section{Theoretical framework \\ Normative ethics and ethical dilemmas}

The current study drew on three prominent theories that underpin the examination of normative ethics in view of the nascent, fragmented literature that explores employees' perceptions towards normative ethics within an organisation. These theories are as follows: stockholders, stakeholders and social contract theories. Friedman (1999), the main proponent of stockholders theory, posits that managers (and employees) as instruments of stockholders must abide by the norms and rules of society when they conduct their business. As such, these human beings are compelled to abstain from social vices like corruption, fraud and dishonesty in their business dealings.

However, the application of social norms and rules is not a simple, straightforward exercise of pairing a business motive to a particular ethical consideration because SMME employees often make tight-rope decisions and choices based on limited courses of actions. Employees may be under pressure to sacrifice a moral principle in pursuit of their business or self-interests when confronted with these eitheror-situations. Ideally, while refraining from social vices should be the norm, Jackson (1996) laments that in the real business world, business operators such as SMME employees are often confronted with two kinds of difficulties - namely the difficulty of identification and difficulty of compliance. Employees display the difficulty of identification when they struggle to pin down what their actual duty is in a particular situation. Employees are confronted with a difficulty of compliance when they fail or choose not to do their duty once they recognise it.

Stakeholders theory, another normative ethics theory, which has been extensively written about (Clarkson 1995; Donaldson \& Preston 1995) emphasises that management of enterprises must take cognisance of all parties affected by their business activities whenever ethical dilemmas arise and are being resolved. The business, therefore, should take concerted steps to prevent the violation of shareholders, employees, customers, suppliers and society at large in their conduct of business. An ethical perspective on stakeholders, therefore, enables firms to gauge the impact of their decisions on several groups of people within and outside the organisation (Vivi \& Yothmontree 2002).

Given the diversity of stakeholders that interact with SMMEs, the process of reconciling SMME interests with stakeholder aspirations becomes an inexorably complex exercise that straddles personal motives, business intentions and broader social demands and expectations. Ethical dilemmas are bound to arise when SMMEs struggle to reconcile these various contenting interests in their fulfilment of their business responsibilities. Dees and Starr (1992) describe four main ethical dilemmas that business operations regardless of size, namely moral conflict, prudential tension, personal-social conflict and moral ambiguity. Moral conflict is when personal values contradict each other. Prudential tension occurs when one realises that the right action to be taken is not in sync with one's short-term. Personal-social conflict occurs when personal moral values are in conflict with the social environment in which one is operating.

Lastly, moral ambiguity occurs when ethical values and guidelines are not clear and there are no prior examples to emulate. Donaldson (1982) propounded the social contract theory in an attempt to reconcile the economic objectives (especially profit maximisation) of the business and the broader societal goals of well-being such as promoting social development, enhancing empowerment and nurturing good will. The theory is premised on the understanding that business managers should pursue profit objectives in so far as it enhances social well-being because the society at large allows businesses to be formed and sustained. Yet, balancing economic and social objectives is not a simple logic matter as SMME entrepreneurs and their employees are often confronted with unique ethical dilemmas arising from various organisations such as resource constraints and environmental factors that affect the ethical standards and values of an enterprise (Declerq \& Dakhli 2009; Harris, Sapienza \& Bowie 2009; Volkman \& Berg 2012). Payne and Joyner (2006) state that entrepreneurs face ethical dilemmas involving their own values, organisational culture, employee well-being, customer satisfaction and external accountability which complicate their pursuit of ethical values and standards. The SMMEs' realisation of societal demands may be constrained by relatively limited market presence, product and service demand fluctuations, forceful competitive attacks and lack of support from suppliers and distributors (Bennett et al. 2012), which pressurise SMMEs to make ambiguous decisions that compromise their ethical practices.

It is critical to demonstrate how the aforementioned issues, namely virtue ethics, deontology and consequentialism against stockholders and stakeholders theories fit together. From a theoretical perspective, the stakeholder theory is a 
critique of the stockholder's minimalist perspective that puts great emphasis on the accountability of the management and board of directors to the investors of the company to the exclusion of stakeholders who are also implicated in business operations. The stockholder theory asserts that those who control and manage a company (i.e. directors, managers, the chief executive or executive directors) do so for the benefit of shareholders and are effectively accountable to them (SamaLang \& Njonguo 2016). The stakeholder theory challenges and extends this argument by contending that management and directors owe their duties not only to the shareholders but also to the company's employees, customers and the community (Sama-Lang \& Njonguo 2016). As such, the stockholder theory can be conceived as a subset of the stakeholder theory as it (stockholder theory) only captures management's relationship with one of the stakeholders (i.e. investors), while the latter is broader and encapsulates a range of stakeholders.

Although stockholder theory can be conceived as a subset of stakeholder theory, both theories dictate and inform normative ethics, hence normative ethics are subsumed in these theories. Normative ethics comprise rule-based ethics, which define in prescriptive terms the courses of moral behaviour and conduct (often through a code of ethics), and virtue-based ethics, which generally emphasise entrenching good in society. The difference is that rule-based ethics seems to give preponderance to employees and management's internal ethical conduct even though they do not necessarily preclude their external conduct with external stakeholders. More so, in the event of their breach by management and employees, rule-based ethics are enforceable through rewards, deterrents and sanctions drawing on the moral code. Virtue-based ethics seem to focus more on the organisational workforce and management's good will and good relations with their world (government, community environment) even though they do not ignore internal stakeholders (employees, employers, investors, financiers). However, virtue-based ethics are hard to enforce or may not be enforceable. Sama-Lang and Njonguo (2016) distinguished these rule-based on virtue-based ethics by highlighting that although the law prohibits companies from engaging in acts of bribery and corruption (i.e. rule-based ethics), the same law will not compel a company to sponsor water projects or build schools in the locality where it operates. It is the company's knowledge of right and wrong, good and evil, as related to its objectives and sphere of operation, that will compel it to act (virtue-based ethics) (Sama-Lang \& Njonguo 2016). The former could be aligned to stockholder theory and the latter to stakeholder theory because of its focus on the extended community. Lastly, rule-based ethics can be judged on two foundations, their outcomes (a consequentialist perspective) or on their internal goodness (e.g. virtue) without any recourse to their outcomes (deontological perspective).

\section{Methodology \\ Research design}

The study adopted a quantitative approach. The quantitative research design was considered as desirable as findings from such studies can be generalisable to the entire population, and claims based on findings from quantitative studies (e.g. surveys) are often supported by empirical data (Cohen, Manion \& Morrison 2007; Saunders, Lewis \& Thornhill 2009). Apart from that, the outcome of quantitative studies can be statistically summarised and tested for its significance.

\section{Research strategy}

The survey approach was used to gather data. A structured questionnaire characterised by close-ended questions was used in the data collection process. Probability sampling was used for the selection of the sample upon which the questionnaire was administered.

\section{Target population}

The target population for this study comprised 118 employees from the four branches of an indigenous-owned fast-food firm in Zimbabwe. Of this population, a sample of 108 respondents was subsequently surveyed. The surveyed employees came from various levels of the organisation, that is, from managerial, team leaders to those at the operational levels.

\section{Measuring instrument}

The questionnaire employed Lickert-scale questions to determine employee perceptions of customer-related and work-related ethical scenarios presented to them. The customer-related scenarios had 6 items, while the workrelated scenarios had 11 items. The categories of ethical scenarios were adapted from Abratt et al.'s (1999) research instrument. In the cited study, the scales used exhibited satisfactory reliability levels with Cronbach's alpha coefficients of above the minimum acceptable level of 0.6 (0.602 for work-related scenarios and 0.7030 for customerrelated scenarios). George and Mallery (2016) proposed the following guidelines for evaluating $\alpha$ value: $>0.9$ excellent, $>0.8$ good, $>0.7$ acceptable, $>0.6$ questionable, $>0.5$ poor and $\leq 0.5$ unacceptable.

Instead of a five-item scale, however, a three-item scale was used for the current study to prevent possible ambiguity to respondents, who were all non-native English speakers. The respondents had to choose between (1) wrong, (2) indifferent and (3) not wrong/appropriate for all ethical scenarios presented to them. It is important to note, however, that the use of a narrow scale has the effect of lowering the reliability of the measuring instrument (Pallant 2013). These scenarios related to comprehensive situations related to customer care and work in the retail sector. The validity of the instrument was safeguarded because pre-validated items were used. The last component of the questionnaire on employees' ethical perceptions was self-developed. Here, the respondent chose amongst the following options: (1) yes, (2) no and (3) Not sure.

\section{Data collection}

The permission to conduct the study was sought and granted by respective branch managers of the fast-food firm. 
The researcher, with the assistance of branch managers and shift supervisors, distributed the questionnaires to the respondents during their different work shifts. Using the pick and drop method, data were collected over a 2-week period. All the 108 distributed questionnaires were successfully completed and returned to the researchers, giving a $100 \%$ response rate.

\section{Data analysis}

Descriptive and inferential statistics were used to analyse the data. As such, frequencies of responses to each question were derived and percentages were calculated. Further, the Mann-Whitney and Kruskal-Wallis tests, which are nonparametric techniques, were used to ascertain any differences in the composite mean scores for responses to work-related and customer-related ethical dilemmas on the basis of specified demographic factors. These techniques were considered because of their less stringent requirements on the dataset being analysed. This was done using statistical software, Statistical Package for the Social Sciences 19.

\section{Results}

\section{Demographic factors}

Table 1 shows the diverse demographic characteristics of respondents who participated in the study.

A cursory examination of this data reveals that most respondents were female $(80.6 \%)$, ordinary workers $(77.8 \%)$, were aged 25 years or below (81.5\%) and had, at most, secondary level education (94.4\%).

Findings from the data collection process are divided into three sub-categories, that is, employee responses to workrelated and customer-related ethics scenarios, differences in employee responses to ethics scenarios on the basis of demographic factors and their perceptions of organisational ethics.

TABLE 1: Demographic characteristics of respondents.

\begin{tabular}{llll}
\hline Characteristics & Variable & Frequency & $\mathbf{\%}$ \\
\hline Gender & Female & 87 & 80.6 \\
& Male & 28 & 19.4 \\
Level in the organisation & Total & 108 & 100 \\
& Student & 12 & 11.1 \\
& Ordinary worker & 84 & 77.8 \\
& Supervisor & 9 & 8.3 \\
Age group & Manager & 3 & 2.8 \\
& Total & 108 & 100 \\
& 25 years and below & 88 & 81.5 \\
& 26-35 years & 6 & 5.6 \\
& 36-45 years & 12 & 11.1 \\
& 46-55 years & 2 & 1.9 \\
Level of education & Total & 108 & 100 \\
& Secondary & 102 & 94.4 \\
& College & 3 & 2.8 \\
& University & 3 & 2.8 \\
& Total & $\mathbf{1 0 8}$ & $\mathbf{1 0 0}$ \\
\hline
\end{tabular}

\section{Work-related scenarios}

About $30 \%$ of the respondents viewed giving a friend or relative a discount which they did not deserve as wrong; $41.7 \%$ were indifferent, while $27.8 \%$ said it was not wrong. Respondents were also requested to express their feeling towards taking sales from fellow employees. A total of $30.6 \%$ indicated that this was wrong, $25 \%$ were indifferent and $44.4 \%$ said this was not wrong. The majority of respondents (61.1\%) regarded falsifying $1 \mathrm{~s} h$ worked as wrong. Of the total respondents, $27.8 \%$ were indifferent, while $11.1 \%$ viewed it as not wrong.

About $52.8 \%$ of the respondents indicated that keeping the last product on the shelf for oneself instead of customers was wrong, while $25 \%$ were indifferent. The remaining $22.2 \%$ said that such a practice was not wrong. The findings also suggest that the bulk of respondents $(72.2 \%)$ regarded failure to report theft because of pressure from a fellow employee as wrong. However, $16.7 \%$ were indifferent, while $11.1 \%$ saw nothing wrong in the action.

A majority (63.9\%) of respondents considered the keeping of free samples meant for distribution to customers as wrong and $25 \%$ were indifferent. The remainder $(11.1 \%)$ indicated that it was not wrong.

Overall, the pattern of responses demonstrates that a majority of respondents regarded the presented work-related ethical situations as morally wrong. It is only in one instance of taking sales from fellow employees that the majority of respondents felt it was not ethically wrong.

\section{Customer-related scenarios}

Respondents were asked how they felt about charging a customer full price on a sale item. The majority of respondents (55.6\%) conceived this practice to be wrong, while $22.2 \%$ were indifferent. The rest $(22.2 \%)$ saw nothing wrong with in action.

Respondents were also asked to indicate whether they approved the withholding of information on an upcoming sale on a product that a customer is about to buy. Of the total respondents, $63.9 \%$ showed disapproval, while only $5.6 \%$ expressed approval. The rest $(30.6 \%)$ of respondents were indifferent.

Findings demonstrate that the bulk of respondents (50\%) viewed refusal to take back legitimate returns from customers as wrong. Of the remainder, $33.3 \%$ were indifferent and $16.7 \%$ regarded it as not wrong.

A majority (69.4\%) of the respondents conceived unequal treatment of customers as wrong, while only $11.1 \%$ considered it as not wrong. The remainder (19.4\%) were indifferent.

Closely related to unequal treatment of customers was the employees' practice of attending to customers they conceived 
as better and ignoring those conceived to be bad customers. About $52.8 \%$ of respondents indicated their disapproval of the practice, while $27.8 \%$ saw nothing wrong with it. The remaining $19.4 \%$ were indifferent.

Most respondents (63.9\%) regarded giving incomplete information about product features and functionality as wrong, while $16.7 \%$ said it was not wrong. The remaining $19.4 \%$ indicated that they were indifferent.

About $63.9 \%$ of the respondents regarded making false promises to customers as wrong, while $11.1 \%$ indicated that it was not wrong. The remainder $(25 \%)$ were indifferent.

Furthermore, an overwhelming majority (86.1\%) of the respondents indicated that it was wrong to deliberately give wrong change to customers. Only 5.6\% saw nothing wrong with this practice, while $8.3 \%$ were indifferent.

Lastly, respondents were asked to indicate how they viewed the buying of products by sales staff before these are made available to customers. Of the total respondents, 58.3\% viewed this practice as wrong, while $16.7 \%$ saw nothing with it. The remainder $(25 \%)$ were indifferent.

From the above presentation, it is evident that a majority of the respondents viewed all the presented ethical situations as morally wrong.

\section{Tests for statistical difference}

A Kruskal-Wallis rank sum test was conducted to assess if there were significant differences in the employees' responses to workand customer-related ethics scenarios amongst the different age categories. The results are presented in detail in Table 2.

The results of the Kruskal-Wallis test were significant for work-related ethics scenarios $\left(\mathrm{x}^{2}(3), 12.332, p=0.006\right)$ but not significant for customer-related scenarios $\left(x^{2}(3), 3.751\right.$, $p=0.29)$. This means that the differences in the mean scores for the workers' responses to work-related scenarios were statistically significant. In the absence of a specific post-hoc test for the Kruskal-Wallis rank sum test, we paired the various age groups and conducted the Mann-Whitney test on them. This was done so as to identify the particular pairs of age groups where the significant differences in the mean scores for work-related scenarios lay. Significant differences were noted only between the '25 years and below' and the '26 to 35 years' ( $u=71.000,-3.007, p=0.003)$. However, the differences were not significant for customer-related scenarios.

A Mann-Whitney test was also conducted to explore the impact of gender on the respondents' perception of workand customer-related ethics scenarios. Respondents were divided into two groups according to gender, which are female and male. The results are presented in detail in Table 3.

On analysis, the results show that there were no significant differences on the basis of gender in the scores for work-related and customer-related ethics $(U=830, z=-0.579$, $p=0.563$ and $U=850.5, z=-0.494, p=0.621$, respectively).

Furthermore, a Kruskal-Wallis rank sum test was also used to determine whether there were significant differences in the perceptions of work-related and customer-related ethics scenario scores amongst members at different levels of the organisation. The results are shown in Table 4.

A closer look reveals that the results of the Kruskal-Wallis test were significant $\left(\chi^{2}[3]=14.865, p<0.002\right.$ [work-related scenarios] and $\chi^{2}[3]=9.555, p=0.023$ [customer-related scenarios]), indicating that the differences in mean ranks of work-related and customer-related scenario scores were statistically significant across categories of employee levels in the organisation. To identify where the actual differences lie,

TABLE 2: Results of the Kruskal-Wallis rank sum test with age as the grouping variable.

\begin{tabular}{|c|c|c|c|c|c|c|}
\hline Scenarios & Age group & $N$ & Mean rank & Chi-square & Degrees of freedom & Asymptotic significance \\
\hline \multirow[t]{5}{*}{ Work-related } & 25 years and below & 88 & 58.46 & 12.332 & 3 & 0.006 \\
\hline & $26-35$ years & 6 & 20.08 & - & - & - \\
\hline & $36-45$ years & 12 & 43.38 & - & - & - \\
\hline & $46-55$ years & 2 & 25.5 & - & - & - \\
\hline & Total & 108 & - & - & - & - \\
\hline \multirow[t]{5}{*}{ Customer-related } & 25 years and below & 88 & 55.86 & - & - & - \\
\hline & $26-35$ years & 6 & 38.5 & 3.751 & 3 & 0.29 \\
\hline & $36-45$ years & 12 & 57.5 & - & - & - \\
\hline & $46-55$ years & 2 & 24.5 & - & - & - \\
\hline & Total & 108 & - & - & - & - \\
\hline
\end{tabular}

TABLE 3: Results of the Mann-Whitney $U$ with gender as the grouping variable.

\begin{tabular}{|c|c|c|c|c|c|c|c|c|}
\hline Scenarios & Gender of respondent & $N$ & Mean rank & Sum of ranks & Mann-Whitney U & Wilcoxon W & $\mathbf{Z}$ & Asymptotic significance (2-tailed) \\
\hline \multirow[t]{3}{*}{ Work-related } & Female & 87 & 54.85 & 4717 & 830 & 1061 & -0.579 & 0.563 \\
\hline & Male & 21 & 50.52 & 1061 & - & - & - & - \\
\hline & Total & 108 & - & - & - & - & - & - \\
\hline \multirow[t]{3}{*}{ Customer-related } & Female & 87 & 53.78 & 4678.5 & 850.5 & 4678.5 & -0.494 & 0.621 \\
\hline & Male & 21 & 57.5 & 1207.5 & - & - & - & - \\
\hline & Total & 108 & - & - & - & - & - & - \\
\hline
\end{tabular}


TABLE 4: Results of the Kruskal-Wallis rank sum test with level in the organisational structure as the grouping variable.

\begin{tabular}{|c|c|c|c|c|c|c|}
\hline Scenarios & Level in organisational structure & $N$ & Mean rank & Chi-square & Degrees of freedom & Asymptotic significance \\
\hline \multirow[t]{5}{*}{ Work-related } & Student & 12 & 38.17 & 14.865 & 3 & 0.002 \\
\hline & Ordinary worker & 84 & 59.26 & - & - & - \\
\hline & Supervisor & 9 & 43.5 & - & - & - \\
\hline & Manager & 3 & 3.33 & - & - & - \\
\hline & Total & 108 & - & - & - & - \\
\hline \multirow[t]{4}{*}{ Customer-related } & Student & 12 & 48.5 & 9.555 & 3 & 0.023 \\
\hline & Supervisor & 9 & 50.5 & - & - & - \\
\hline & Manager & 3 & 3.5 & - & - & - \\
\hline & Total & 108 & - & - & - & - \\
\hline
\end{tabular}

TABLE 5: Results of the Kruskal-Wallis rank sum test with highest level of education as the grouping variable.

\begin{tabular}{|c|c|c|c|c|c|c|}
\hline Scenarios & Highest level of education & $N$ & Mean rank & Chi-square & Degrees of freedom & Asymptotic significance \\
\hline \multirow[t]{4}{*}{ Work-related } & Secondary & 102 & 56.76 & 14.707 & 2 & 0.001 \\
\hline & College & 3 & 11.67 & - & - & - \\
\hline & University & 3 & 3.33 & - & - & - \\
\hline & Total & 108 & - & - & - & - \\
\hline \multirow[t]{4}{*}{ Customer-related } & Secondary & 102 & 57.5 & 17.181 & 2 & 0.000 \\
\hline & College & 3 & 3.5 & - & - & - \\
\hline & University & 3 & 3.5 & - & - & - \\
\hline & Total & 108 & - & - & - & - \\
\hline
\end{tabular}

we paired the employee categories and conducted the MannWhitney test as a post-hoc test measure. Significant differences in the mean scores for work-related scenarios were identified in the following pairs of employee categories: Student-Ordinary worker $(u=296.200, z=-2.292, p=0.022)$, Ordinary worker-Manager $(u=2.000, z=-2.913, p=0.004)$ and Supervisor-Manager $(u=2.000, z=-2.161, p=0.031)$. Apart from this, significant differences in the mean scores for customer-related scenarios were identified in the following pairs of employee categories: Student-Manager $(u=0.000$, $z=-2.714, p=0.004)$ and Ordinary worker-Manager $(u=0.000$, $z=-2.972, p=0.003)$.

Furthermore, the Kruskal-Wallis rank sum tests conducted on the data also revealed significant differences amongst employees with different levels of education on their responses to both work-related and customer-related ethics scenarios $\left(\chi^{2}(2)=14.707, p=0.001\right.$ and $\left.\chi^{2}(2)=17.181, p=0.000\right)$ respectively. More details are shown in Table 5.

In addition to the preceding test, we paired the 'highest level of education' categories and conducted the Mann-Whitney test on them as a post-hoc measure. Significant differences in the mean scores for work-related scenarios were identified in the following pairs of categories: Secondary level-College level $(u=22.000, z=$ -2.546, $p=0.011)$ and Secondary level-University level $(u=$ $22.000, z=-2.937, p=0.003)$. In addition, significant differences in the mean scores for customer-related scenarios were identified in the following pairs of categories: Secondary level-College level $(u=0.000, z=-2.974, p=0.003)$ and Secondary levelUniversity level $(u=0.000, z=-2.974, p=0.003)$.

\section{Ethical perceptions}

The ethical perceptions of employees who participated in the study are presented in Table 6 .
TABLE 6: Employees' perception of the organisational ethics environment.

\begin{tabular}{|c|c|c|c|}
\hline \multirow[t]{2}{*}{ Awareness } & \multicolumn{3}{|c|}{ Responses } \\
\hline & Yes (\%) & Not sure (\%) & No $(\%)$ \\
\hline $\begin{array}{l}\text { Of whether firm has integrity as one of its } \\
\text { core values }\end{array}$ & 38.89 & 41.67 & 19.44 \\
\hline Of whether firm has code of ethics & 38.9 & 44.44 & 16.67 \\
\hline $\begin{array}{l}\text { Of whether employees are given induction } \\
\text { training on the firm's ethical values }\end{array}$ & 44.4 & 41.67 & 13.89 \\
\hline $\begin{array}{l}\text { Of whether in-house seminars and training } \\
\text { on ethics are given to employees }\end{array}$ & 11.1 & 72.22 & 16.67 \\
\hline $\begin{array}{l}\text { Of whether ethical conduct is part of } \\
\text { promotion criteria }\end{array}$ & 2.8 & 36.11 & 61.11 \\
\hline Of whether ethical conduct is rewarded & 30.6 & 27.78 & 41.67 \\
\hline
\end{tabular}

Table 6 summarises the findings on SMME employees' perceptions of various ethical aspects within their organisation. A majority of respondents were either not aware of or responded negatively to this question on their perceptions of organisational ethics. Only 2.8\% of employees affirmed that ethical conduct was rewarded in their organisation, while the remainder either did not know or were non-committal. In the same vein, when quizzed on whether ethical conduct was part of the criteria for promotion, only $11.1 \%$ responded positively. It was only on the question of whether employees were inducted on the ethical conduct of the firm that a majority of respondents $(72.2 \%)$ responded in the affirmative.

\section{Discussion}

This study explored the various ethical scenarios that employees in an indigenous fast-food firm would be confronted with on a daily basis. The same study solicited these employees' responses to situations requiring ethical judgement. The findings indicate that most respondents found workplace scenarios presented to them as morally wrong. These findings corroborate findings from extant literature on the ethical sensitivity of SMME employees operating in 
emerging economies (Abratt et al. 1999; Phatshwane 2013; Storsletten \& Jakobsen 2015) as well as the social responsibility of the organisation to the broader society as espoused in the social contract theory (Donaldson 1982). As Storsletten and Jakobsen's (2015) study suggests, employees are increasingly encouraged to be aware of and to question their firm's core values, strategies and concrete actions especially in contexts where participative management and value-based leadership are considered key values for the realisation of social and environmental responsibility. This call resonates with an earlier exhortation for employees in the retail sector to be aware of the importance of ethical conduct (Abratt et al. 1999). The fact that a majority of employees found most workplace scenarios presented to them as morally wrong buttresses the mainstream literature's recognition of the value of business ethics for the survival of such organisations.

Another finding was that there were significant differences in employees' reactions to work-related ethical dilemmas on the basis of age categories. However, no such differences were noted for customer-related scenarios. This possibly means that people from different age categories react similarly to customer-related ethical challenges, but react differently to work-related ethical predicaments. The preceding findings confirm Wang and Calvarno's (2015) observation that the results on the relationship between respondents' ages and their reaction to the ethical climate in their respective organisations were inconclusive. This inconclusiveness is prevalent in climates where corruption and unethical behaviour is rampant. In an environment that is rife with unethical behaviour, it becomes increasingly difficult to make ethical decisions, or to objectively assess the implications of a decision (Van der Walt, Jonck \& Sobayeni 2016). The findings relating to work-related scenarios however confirm claims that individuals generally develop a moral compass as they grow older (Kim et al. 2016). This finding also resonates with Van der Walt et al.'s (2016) findings that there were statistically significant generational differences amongst Baby Boomers, Generation $X$ and Generation $Y$ for certain facets of work ethics such as hard work and delay of gratification. However, Sweeney, Arnold and Pierce (2009) question the significance of the effect of age on an individual's ethical judgement.

It was also postulated that respondents of different gender categories responded differently to both customer-related and work-related dilemmas. Contrary to conventional wisdom, the current study did not detect a significant difference between genders on both categories of ethical dilemmas. This may mean that when presented with the same ethical scenarios, both genders respond in similar ways to ethical challenges at the workplace. Perhaps both genders are exposed to the same ethical codes and ethical awareness campaigns within their organisation. The results contradict those of some scholars whose studies revealed significant difference across genders (Atakan, Burnaz \& Topcu 2007; Wang \& Calvarno 2015).

The study also examined the influence of one's position in the organisational hierarchy on his or her reaction to customer-related and work-related reactions to ethical dilemmas. The results confirmed significant differences across levels of organisational hierarchy for both customerrelated and work-related dilemmas. This finding contradicted Phatshwane's (2013) findings on the ethical sensitivity of small and large business managers in Botswana to the views of the key personnel. Phatshwane (2013) found no significant differences between the two groups of managers regarding most questions that queried respondents' ethical value statements. However, findings corroborate Bobek, Hageman and Radtke's (2015) idea that individuals in leadership roles respond differently to ethical challenges when compared to those in non-leadership roles. In fact, Ardichvili, Jondle and Kowske (2012) observed that organisational members in nonleadership positions are accommodating to ethically suspect behaviour. In the context of the developing world, the results may possibly be explained by the generally poor remuneration in the workplace, which increases the attractiveness of deviant behaviour as a way of getting additional income.

Another question was whether there were any statistically significant differences in responses to customer-related and work-related dilemmas amongst individuals of different educational backgrounds. The results were significant for both categories of dilemmas, with those individuals with better educational qualifications reporting positive ethical perceptions compared with their counterparts. The study findings corroborate the findings on the positive influence of education on morality (Honeycutt Jnr et al. 2001; Singhapakdi et al. 1999).

A clear polarity of views emerged on employees' perceptions of ethical values of their organisation (i.e. organisational ethics). This lack of consensus was evident on questions relating to employees' knowledge of whether the firm had integrity as one of its core values, whether the firm had a code of ethics and whether the firm offered in-house seminars and training as part of the induction on ethical issues. As small firms are often resource constrained and may not have a written ethical code which employees are required to abide by, firm managers' and owners' behaviour modelling practices may be critical to employees' increased sensitivity to ethical issues. Literature highlights that individuals (e.g. employees) learn appropriate behaviour by modelling the behaviour of others whom they consider as important, for example, parents, siblings, peers, teachers, superiors and so forth (Luthans \& Kreitner 1975; Sama-Lang \& Njonguo 2016). As such, powerful superiors in SMMEs such as manager and owners need to demonstrate exemplary ethical behaviour, which may wield great influence in shaping, either directly or indirectly, ethical decisions of their subordinates (Sama-Lang \& Njonguo 2016). Behaviour modelling could be better than establishing ethical codes in SMMEs. In a study on the communication of ethics in British and Spanish small firms, Spence and Loranzo (2000) reported on the likely ineffectiveness of formal business tools such as formal codes of ethics and social and ethical standards as ways of communicating ethical policies and generating voluntary commitment to specific rules. They attributed the 
absence of formal codes of practice, standards and mission statements in small UK firms to the opportunity for dialogue and management without the imposition of formal and bureaucratic controls, which often lead to the mistrust of bureaucracy and reliance on informal control mechanisms (Spence \& Loranzo 2000).

Similarly, a study conducted by Slack et al. (2014) on employees' knowledge of the four strands of CSR (of which ethical responsibility is a component) suggests that employees lacked a detailed knowledge of company CSR policies or the four key strands. A majority of employees either had vague understanding of the CSR concept. We inferred that the documentation of ethical codes and standards does not translate into wide scale rollout of and total commitment to the implementation of ethical practices at lower levels. Consistent with stakeholder theory, the divergence of views on the aforementioned ethical matters could be symptomatic of the ambivalence of owners and managers with regard to consideration of all parties implicated in their business activities involving ethical issues.

The fact that $44.4 \%$ of respondents affirmed that their organisation held induction training courses to new employees and in-house seminars to existing employees on ethical issues while $13.8 \%$ of employees disagreed is revelatory. It gives an impression that while there is a good sense of ethical training in the organisation, these seminars may not be held frequently. These findings resonate with Cant's (2012) claim that in the contemporary complex business environment, which is stressful for small businesses to survive, small businesses are pressured to pursue profit and survival at the expense of operating ethically.

On whether ethical behaviour was rewarded or not in the organisation, $97.1 \%$ of respondents either said it was not or they were not sure of it. It can be inferred from these responses that perhaps there was no reward in the organisation expressly meant for ethical behaviour. It can be inferred that as SMMEs do not have a moral code governing employees' ethical behaviour, it is an unspoken rule that employees should just behave ethically or risk being dismissed. As such, it would be unrealistic to expect employers to compensate employees for good ethical conduct as it is an unwritten component of their ethical responsibility. It is suffice to say that this finding seems to mirror Cant's (2012) view that ethical behaviour and the perception towards ethics are not formulated from the morals and beliefs of individuals on its own but rather as a result of the interaction with external factors in the business environment.

When asked whether senior management at times allowed the breaking of moral rules for the firm's benefit, a majority of respondents were either not sure or disagreed. As the percentage of those who were not sure was almost similar to that of those who agreed, it is unclear whether the overall result can be conceived as negative or positive. The clear spit of opinion further complicates the ambivalence manifested in those who were unsure about managerial practices. The ambivalence of responses could speak to the ad hoc nature in which management fulfilled their ethical responsibilities. It is not enough for an organisation to have a corporate code of ethics if the intention is to cherry-pick values and standards in the implementation process. The company must therefore enforce ethical standards particularly through managerial example (Carroll \& Buccholtz 2014; Fritz, Arnett \& Conkel 1999).

\section{Conclusion and managerial implications}

Except for two scenarios (i.e. giving a friend or relative a discount which they did not deserve and taking sales from fellow employees) for which employees expressed polarity of views, these respondents were generally apprehensive of a majority of ethical violations presented to them. These findings suggest that employees in organisations appreciate the value of ethical conduct for business survival (Ferrell, Fraedrich \& Ferrel 2014; Hartman 2011; Trevino \& Nelson 2010). Although this result is commendable, employees' approval of the two aforementioned ethical violations demonstrates the need for increased ethical sensitivity amongst employees through reprimanding such behaviour and increasing moral guidance through ethical dialogue with employees.

Employees also expressed disapproval of the ethical violation embodied in the customer-related scenarios presented to them. Such disapproval is indicative of the possible existence of consistent and appropriate ethical training on customer service within the organisation. Given the proximity and intimacy of relations between SMME employees and customers and the significance of customers to SMME profitability, the employees' disapproval of ethical violations relating to customers would be inevitable. While such ethical sensitivity is commendable, it is vital to acknowledge that this practice was far from universal. Therefore, SMMEs should be exhorted to increase their employees' sensitivity to ethical matters to ensure widespread acceptance of ethical conduct. Senior management may need to provide best examples of good ethical conduct to apprehend simmering immoral behaviour and encourage explicit acceptance of good moral conduct. Operational level employees are more likely to adopt ethical conduct if strategic people in the organisation lead by example in ensuring ethical acquiescence (Antoncic \& Antoncic 2011; Koh \& Boo 2004). As SMMEs may not have the financial resources to appoint an ethical compliance officer to drive all ethical compliance programmes, senior management should be briefed about ethical compliance and employees would be expected to take ethical responsibility. However, the extent of their ethical sensitivity is limited to the level to which they are exposed to ethical issues by their employers. Therefore, few employees are aware of broader ethical issues beyond the unwritten rule about good ethical behaviour. As resource constraints may complicate the wider rollout of ethical practices through 
training and seminars on ethical matters at the lower levels only managers and supervisors in the fast-food industry should be trained in ethical responsibility and these individuals can then appraise employees of these issues. Verschoor (2000) advocated for a value-based approach to implementing ethics within contemporary business enterprises as opposed to the traditional top-down approach. Our study contradicts this view by suggesting that business ethics can be made more pervasive in small firms by training supervisors who can share their ethical knowledge with subordinates rather than developing a detailed ethical code, which could be more demanding resource-wise.

Employees were not aware of any rewards for ethical conduct by employees. It is plausible that this lack of compensation arose from management's belief that ethical conduct was already a component of the good behaviour expected of employees and hence there was no need for additional benefits. Given the profound connection between a company's ethical culture and employee engagement, managers and supervisors should work actively to demonstrate a commitment to ethics (Ethics Resource Centre 2010) by modelling exemplary ethical behaviour for employees to emulate.

There was a clear polarity of views on whether the firm had integrity as one of its core values, whether the firm had a code of ethics and whether management accepted the violation of moral rules for the benefit of the organisation. The ambivalent and positive views were both well represented in employees' responses to the three questions, suggesting that although the organisation might have had a code of ethics and had integrity as one of its core values, these could have been undocumented or were arbitrarily effected by management. This may require the clear documentation and consistent application of the code of ethics and the demonstration of integrity in business operations. As for management's violation of moral rules, the ambivalence of responses could mean guesswork on the part of respondents since many of fast-food employees may not necessarily have higher education qualifications, which capacitate them to make moral judgements on business decisions. DeTienne et al. (2012) suggest that as one's education level is often consistent with position in a firm, less educated employees are less situated to know about ethical policies and to engage with organisational authority on such matters. More so, as decisions may be handed down in authoritarian ways in SMMEs because of the significant role of managers and owners in various matters of the business, few employees may be appraised of such decision making. The provision of induction and on-the-job training on ethical matters would leverage employees' sensitivity on ethical matters.

\section{Acknowledgements}

The authors wish to acknowledge the input of the anonymous reviewers which gave shape to this article.

\section{Competing interests}

The authors declare that they have no financial or personal relationship(s) that may have inappropriately influenced them in writing this article.

\section{Authors' contributions}

P.R. wrote all sections of this article. T.M.N. designed the research methodology and did the data analysis.

\section{References}

Abratt, R., Bendixen, M. \& Drop, K., 1999, 'Ethical perceptions of South African retailers: Management and sales personnel', International Journal of Retail \& Distribution Management 27(2), 91-105. https://doi.org/10.1108/0959055991 0258616

Antoncic, J.A. \& Antoncic, B., 2011, 'Employee satisfaction, intrapreneurship and firm growth: A model', Industrial Management \& Data Systems 111(4), 589-607. https://doi.org/10.1108/02635571111133560

Ardichvili, A., Jondle, D. \& Kowske, B., 2012, 'Minding the gap: Exploring differences in perceptions of ethical business cultures among executives, mid-level managers
and non-managers', Human Resource Development International 15(3), 337-352. https://doi.org/10.1080/13678868.2012.687625

Assad, A., 2013, 'The ethical problems of small businesses', viewed 22 June 2015, from http://www.ehow.com/info_8311114_ethical-problems-small-businesses.html.

Atakan, M.G.S., Burnaz, S. \& Topcu, Y.I., 2007, 'An empirical investigation of the ethical perceptions of future manaters with a special emphasis on gender - Turkish case', Journal of Business Ethics 82, 573-586. https://doi.org/10.1007/s10551-007-9577-z

Barnett, T. \& Schubert, E., 2002, 'Perceptions of the ethical work climate and covenantal relationships', Journal of Business Ethics 36(3), 279-290. https://doi. org/10.1023/A:1014042613106

Basran, S., 2012, 'Employee views of ethics at work: 2012 continental Europe survey', Institute of Business Ethics 47, 1-42.

Bennett, V.M., Pierce, L., Snyder, J.A. \& Toffel, M.W., 2013, 'Customer-driven misconduct: How competition corrupts business practices', Management Science 59(8), 1725-1742. https://doi.org/10.1287/mnsc.1120.1680

Biti, T., 2015, Zimbabwe: From haemorrhage to stability: A personal journey, Essays Centre for Global Development, viewed 22 June 2015, from https://www.cgdev. org/publication/ft/zimbabwe-hemorrhage-stability-personal-journey

Bobek, D.D., Hageman, A.M. \& Radtke, R.R., 2015, 'The influence of roles and organizational fit on accounting professionals' perceptions of their firms' ethical environment', Journal of Business Ethics 126(1), 125-141. https://doi. org/10.1007/s10551-013-1996-4

Botha, H.J., 2012, 'Investigating the ethical considerations faced by small business entrepreneurs in the informal sector: Zandspruit Township', Johannesburg, viewed 22 June 2015, from http://www.uj.ac.za/EN/Faculties/management/ departments/CSBD/Documents/2010\%20CSBD\%20Conference $\% 20$ Docs/BS department

Boylan, M., 2002, Basic ethics, Prentice Hall, Upper Saddle River, NJ.

Boyle, D., 2002, 'Ethical determinants for generations $x$ and $y$ ', Journal of Business Ethics 93(3), 465-495.

Brizek, M.G., 2014, 'Explaining corporate entrepreneurship: A contemporary literature Investigation', Journal of Management \& Marketing Research 14, 1-13.

Cant, M., 2012, 'Small business attitudes towards ethical issues: Survival or ethically correct?', International Business \& Economics Research Journal 11(12), 13471358. https://doi.org/10.19030/iber.v11i12.7414

Cant, M., Wiid, J. \& Kallier, S., 2013, 'Small business owners' perceptions of moral behaviour and employee theft in the small business sector of Nigeria', Gender \& Behaviour 11(2), 5775-5787.

Carroll, A. \& Buchholtz, A., 2014, Business and society: Ethics, sustainability, and stakeholder management, Cengage Learning, New York.

Clarkson, M.B.E., 1995, 'A stakeholder framework for analysing and evaluating corporate social performance', Academy of Management Review 20(1), 92-117.

Cohen, L., Manion, L. \& Morrison, K., 2007, Research methods in education, 6th edn., Routledge, London.

Cornelius, P., Van den Berghe, L. \& Louche, C., 2005, "Good corporate practices in poor corporate governance systems: Some evidence from the Global Competitiveness Report', Corporate Governance: The International Journal of Business in Society 5(3),12-23.

Davoren, J., 2013, 'What is workplace coercion?', viewed 21 June 2015, from http:// smallbusiness.chron.com/workplace-coercion-45211.html

Declerq, D. \& Dakhli, M., 2009, 'Ethical standards and personal strains of the selfemployed', Journal of Business Venturing 24, 477-90. https://doi.org/10.1016/j. jbusvent.2008.04.008

Dees, J.G. \& Starr, J.A., 1992, 'Entrepreneurship through an ethical lens: Dilemma and issues for research and practice', in D. Sexton \& J.D. Kasarda (eds.), The state of the art of entrepreneurship, pp. 89-116, PWS-Kent Publishing, Boston, MA. 
Detienne, K.B., Agle, B.R., Phillips, J.C. \& Ingerson, M.C., 2012, 'The impact of moral stress compared to other stressors on employee fatigue, job satisfaction, and stress compared to other stressors on employee fatigue, job satisfaction, and
turnover: An empirical investigation', Journal of Business Ethics 110(3), 377-391. turnover: An empirical investigation', Journal
https://doi.org/10.1007/s10551-011-1197-y

Dhanesh, S.G., 2012, 'The view from within: Internal publics and CSR', Journal of Communication Management 16(1), 39-58. https://doi.org/10.1108/ 13632541211197987

Donaldson, T., 1982, Corporations and morality, Prentice-Hall, Englewood Cliffs, NJ.

Donaldson, T. \& Preston, L.E., 1995, 'The stakeholder theory of the corporation: Concepts, evidence and implications', Academy of Management Review 20(1), 65-91.

Ethic Resources Centre, 2010, Blowing the whistle on workplace misconduct, Ethics Resources Centre, viewed 20 June 2015, from http://www.ethics.org/files/ u5whistleblowerWP.pdf

Fassin, Y., 2005, 'The reasons behind non-ethical behaviour in business and entrepreneurship', Journal of Business Ethics 60, 265-279. https://doi. org/10.1007/s10551-005-0134-3

Fassin, Y., Van Rossem, A. \& Buelens, M., 2010, 'Small-Business Owner-Managers' perceptions of business ethics and CSR-related concepts', Journal of Business perceptions of business ethics and CSR-related concepts', Journal
Ethics 98(3), 425-453. https://doi.org/10.1007/s10551-010-0586-y

Ferrell, O.C., Fraedrich, J. \& Ferrell, L., 2014, Business ethics: Ethical decision making \& cases, 9th edn., Cengage Learning-Mason, New York.

Friedman, M., 1999, 'The social responsibility or business is to increase its profits', in T.L. Beauchamp \& N.E. Bowie (eds.), Ethical theory and business, 5th edn., pp. 56-61, Prentice Hall, Englewood Cliffs, NJ.

Fritz, J.M., Harden, A.R.C. \& Conkel, M., 1999, 'Organizational ethical standards and organizational commitment', Journal of Business Ethics 20(4), 289-299. https:// doi.org/10.1023/A:1005939325707

Garray, L. \& Font, X., 2012, 'Doing good to do well? Corporate social responsibility reasons, practices and impacts in small and medium accommodation enterprises', International Journal of Hospitality Management 31(2), 329-337. https://doi. org/10.1016/j.ijhm.2011.04.013

George, D. \& Mallery, P., 2016, IBM SPSS Statistics 23 step by step: A simple guide and reference, Routledge, London.

Harris, J.D., Sapienza, H.J. \& Bowie, N.E., 2009, 'Ethics and entrepreneurship', Journal of Business Venturing 24(5), 407-418. https://doi.org/10.1016/j.jbusvent.2009.06.001

Hartman, E.M., 2011, 'Virtue, profit, and the separation thesis: An Aristotelian view', Journal of Business Ethics 99(1), 5-17. https://doi.org/10.1007/s10551-011-0745-9

Holme, C., 2008, 'Do ethics matter?', Industrial and Commercial Training 40(5), 248252. https://doi.org/10.1108/00197850810886487

Honeycutt, E.D., Jr., Glassman, M., Zugelder, M.T. \& Karande, K., 2001, 'Determinants of ethical behavior: A study of autosalespeople', Journal of Business Ethics 32(1), 69-79. https://doi.org/10.1023/A:1010704409683

Hosmer, L.T., 1994, 'It's time for empirical research in business ethics', Business Ethics Quarterly 10(1), 233-242. https://doi.org/10.2307/3857709

Huimin, G. \& Ryan, C., 2011, 'Ethics and corporate social responsibility-An analysis of the views of Chinese hotel managers', International Journal of Hospitality the views of Chinese hotel managers', International Journal of Hos
Management 30(4), 875-885. https://doi.org/10.1016/j.ijhm.2011.01.008

Humphreys, N., Robin, D.P., Reidenbach, R.E. \& Moak, D.L. 1993, 'The ethical decision making process of small business owner/managers and their customers', Journal of Small Business Management 31(3), 9-22.

Innscor Report, 2014, viewed 6 April 2015, from http://www.innscorafrica.com

Institute of Business Ethics, 2007, Business ethics for SMEs, Institute of Business Ethics, London.

Jackson, J., 1996, An introduction to business ethics, Blackwell Publishing, Oxford.

Jamali, D.R., Dirani, A.M. \& Harwood, I.A., 2015, 'Exploring human resource management roles in corporate social responsibility: The CSR-HRM co-creation model', Business Ethics: A European Review 24(2), 125-143. https://doi. model, Business Ethics:
org/10.1111/beer.12085

Kabote, F., Chimutingiza, F. \& Mirimi, K., 2013, 'The impacts of dollarization on Zimbabwe's tourism industry', International Journal of Development and Sustainability 2(2), 653-663.

Kim, E.B., Chen, C., Smetana, J.G. \& Greenberger, E., 2016, 'Does children's moral compass waver under social pressure? Using the conformity paradigm to test preschoolers' moral and social-conventional judgments', Journal of Experimental Child Psychology 150, 241-251. https://doi.org/10.1016/j.jecp.2016.06.006

Klein, S. \& Vorbohle, K., 2010, 'Corporate social responsibility and stakeholder relations-the perspective of German small and medium-sized enterprises', in I.J. Spence \& M. Painter-Marland (eds.), Ethics in small and medium sized enterprises, pp. 215-225, Springer, Dordrecht.

Koh, H.C. \& Boo, E.H.Y., 2004, 'Organisational ethics and employee satisfaction and commitment', Management Decision 42(5), 677-693. https://doi.org/10.1108/ 00251740410538514

Longenecker, J.G., Moore, C.W., Petty, J.W., Palich, L.E. \& Mckinney, J.A., 2006, 'Ethical attitudes in small businesses and large corporations: Theory and empirical findings from a tracking study spanning three decades', Journal of Small Busines Management 44(2), 167-183. https://doi.org/10.1111/j.1540-627X.2006.00162.x

Luthans, F. \& Kreitner, R., 1975, Organizational behavior modification and beyond: An operant and social learning approach, Scott Forsman, Glenview, IL.

Martínez, P. \& Del Bosque, I.R., 2013, 'CSR and customer loyalty: The roles of trust, customer identification with the company and satisfaction', International
Journal of Hospitality Management 35, 89-99. https://doi.org/10.1016/j. ijhm.2013.05.009
Masaka, D., 2011, 'Virtue ethics as a corrective to malpractices in Zimbabwe's economy', Journal of Business Ethics Education 10, 47-60. https://doi. economy', Journal of Busin
org/10.5840/jbee2013103

Mawere, M., 2011, Moral degeneration in contemporary Zimbabwean business practices, African Books Collective, Yaondé.

Mcdaniel, C., Shoeps, N. \& Lincourt, J., 2001, 'Organizational ethics: Perceptions of employees by gender', Journal of Business Ethics 33(3), 245-256. https://doi. org/10.1023/A:1017593508147

Mkono, M., 2012, 'Slow food versus fast food: A Zimbabwean case study of hotelier perspectives', Tourism and Hospitality Research 12(3), 147-154. https://doi. org/10.1177/1467358412470556

Morris, M.H., Schindehutte, M., Walton, J. \& Allen, J., 2002, 'The ethical context of entrepreneurship: Proposing and testing a developmental framework', Journal of Business Ethics 40(4), 331-361. https://doi.org/10.1023/A:1020822329030

Murillo, D. \& Lozano, J.M., 2006, 'SMEs and CSR: An approach to CSR in their own words', Journal of Business Ethics 67(3), 227-240. https://doi.org/10.1007/ s10551-006-9181-7

Okyere, F., 2012, Social responsibility in the SMMEs of the Botshabelo industrial estates, Doctoral dissertation, Central University of Technology, Free State, Bloemfontein.

Paillé, P., Chen, Y., Boiral, O. \& Jin, J., 2014, 'The impact of human resource of Business Ethics 121(3), 451-466. https://doi.org/10.1007/s10551-013-1732-0

Painter-Marland, M. \& Dobie, K., 2009, 'Ethics and sustainability within SME's in SubSaharan Africa; Enabling, constraining and contaminating relationships', African Journal of Business Ethics 14(2), 7-19.

Pallant, J., 2013, SPSS survival manual, 5th edn., McGraw-Hill, London.

Parboteeah, K.P. \& Cullen, J.B. 2013, Business ethics, Routledge, Oxon.

Payne, D. \& Joyner, B., 2006, 'Successful U.S. Entrepreneurs: Identifying ethical decision-making and social responsibility behaviours', Journal of Business Ethics 65, 203-217. https://doi.org/10.1007/s10551-005-4674-3

Phatshwane, P.M.D., 2013, 'Ethical perceptions of managers: A preliminary study of small and medium enterprises in Botswana', American International Journal of Contemporary Research 3(2), 41-49.

Rao, C.P., Singhapakdi, A., Vitell, S.J., Rallapalli, K.C. \& Kraft, K.L., 1996, 'The perceived role of ethics and social responsibility: A scale development', Journal of Business Ethics 15(11), 1131-1140. https://doi.org/10.1007/BF00412812

Research and Markets Report, 2011, Zimbabwe food and drink report 2011, viewed 26 April 2015, from http://www.researchandmarkets.com/reports/1533234/

Reserve Bank of Zimbabwe, 2008, First quarter monetary policy Statement, Reserve Bank of Zimbabwe, Harare, Zimbabwe.

Ruiz-Palomino, P., Martínez-Cañas, R. \& Fontrodona, J.. 2013, 'Ethical culture and employee outcomes: The mediating role of person-organization fit', Journal of employee outcomes: The mediating role of person-organization fit', Journal
Business Ethics 116(1), 173-188. https://doi.org/10.1007/s10551-012-1453-9

Sama-Lang, I. \& Njonguo, A., 2016, 'The stakeholder theory of corporate control and the place of ethics in Ohada: The case of Cameroon', African Journal of Business Ethics 10(1), 97-111. https://doi.org/10.15249/10-1-117

Saunders, M.N., Lewis, P. \& Thornhill, A., 2009, Research methods for business students, 5th edn., Pearson Education, New Delhi.

Seeletse, S.M. \& Ladzani, M.W., 2012, 'Social responsibility in the rural businesses of the North-West Province of South Africa: Coerced or business-driven?', African Journal of Business Management 6(46), 11457-11466. https://doi.org/10.5897/ AJBM12.685

Sharma, D., Borna, S. \& Stearns, J.M., 2009, 'An investigation of the effects of corporate ethical values on employee commitment and performance: Examining the moderating role of perceived fairness', Journal of Business Ethics 89(2), 251-260. https://doi.org/10.1007/s10551-008-9997-4

Shaw, W.H., 2014, Business ethics: A textbook with case, 8th edn., Cengage, Boston, MA.

Singhapakdi, A., Vitell, S.J. \& Franke, G.R., 1999, 'Antecedents, consequences, and mediating effects of perceived moral intensity and personal moral philosophies', Journal of the Academy of Marketing Science 27(1), 19-36. https://doi. org/10.1177/0092070399271002

Slack, R.E., Corlett, S. \& Morris, R., 2015, 'Exploring employee engagement with (corporate) social responsibility: A social exchange perspective on organisational (corporate) social responsibility: A social exchange perspective on organisational
participation', Journal of Business Ethics 127(3), 537-548. https://doi. participation', Journal of Busine
org/10.1007/s10551-014-2057-3

Sledge, S. \& Miles, A.K., 2012, 'Workplace values: Cross-cultural insights from the service industries', Journal of Comparative International Management 15(1), 50-67.

Smith, H.J. \& Hasnas, J., 1999, 'Ethics and information systems: The corporate domain', MIS Quarterly 23(1), 109-127. https://doi.org/10.2307/249412

Spence, L. \& Lozano, J., 2000, 'Communicating about ethics with small firms: Experiences from the UK and Spain', Journal of Business Ethics 27, 43-53. https:// doi.org/10.1023/A:1006417425446

Spence, L.J. \& Rutherford, R., 2003, 'Small business and empirical perspectives in business ethics: An editorial', Journal of Business Ethics 47, 1-5. https://doi. org/10.1023/A:1026205109290

Storsletten, V.M. \& Jakobsen, O.D., 2015, 'Development of leadership theory in the perspective of Kierkegaard's philosophy', Journal of Business Ethics 128(2), 337349. https://doi.org/10.1007/s10551-014-2106-y

Sweeney, B., Arnold, D. \& Pierce, B., 2009, 'The impact of perceived ethical culture of the firm and demographic variables on auditors' ethical evaluation and intention to act decisions', Journal of Business Ethics 93(4), 531-551. https://doi. org/10.1007/s10551-009-0237-3 
Trevino, L.K. \& Nelson, K.A., 2010, Managing business ethics, Wiley, New York, NY.

Van Der Walt, F., Jonck, P. \& Sobayeni, N., 2016, 'Work ethics of different generational cohorts in South Africa', African Journal of Business Ethics 10(1), 52-66. https:// doi.org/10.15249/10-1-101

Van Hooft, S. \& Van Hooft, M.A., 2014, Understanding virtue ethics, Routledge, London. Velasquez, M.G., 2006, Business ethics concept and cases, 6th edn., Pearson, New York. Verschoor, C.C., 2000, 'A study of the link between a corporation's financial performance and its commitment to ethics', Journal of Business Ethics 17(11), 1509-1516.
Vivi, V. \& Yothmontree, S., 2002, 'The impact of ethical considerations in purchase behaviour: A propadeutic to further research', ABAC Journal 22(3), 1-15.

Vivier, E., 2013, "'A tough line to work through": Ethical ambiguities in a South African SME', African Journal of Business Ethics 7(2), 68-79. https://doi.org/10.4103/18177417.123081

Volkman, K. \& Berg, H., 2012, 'Ethical dilemmas in entrepreneurial decision making', Entrepreneurship Theory and Practice 8(2), 1-22.

Wang, L.C. \& Calvano, L., 2015, 'Is business ethics education effective? An analysis of gender, personal ethical perspectives, and moral judgment', Journal of Business Ethics 126(4), 591-602. https://doi.org/10.1007/s10551-013-1973-y 